Available online at https://jurnal.stmikroyal.ac.id/index.php/jurdimas

\title{
PEMBERDAYAAN PEREMPUAN DALAM MEMANFAATKAN SAMPAH KRESEK MENJADI PRODUK BERNILAI EKONOMIS
}

\author{
${\text { Benedhikta Kikky Vuspitasari }{ }^{1} \text {, Deffrinica }}^{2}$, Shanti Veronnica Br Siahaan ${ }^{1}$, Novita ${ }^{1}$ \\ ${ }^{1}$ Kewirausahaan, Institut Shanti Bhuana \\ ${ }^{2}$ Manajemen, Institut Shanti Bhuana \\ email: "kikky@shantibhuana.ac.id
}

\begin{abstract}
Plastic waste is one of the most common plastic wastes around Suka Maju village, the lack of public knowledge in utilizing and processing plastic waste into products of economic value, based on this background, the Shanti Bhuana Institute lecturer community service activity was carried out and involved two students, the purpose of this activity is to provide knowledge about the processing of plastic waste that is often found by mothers in Suka Maju village so that they get new knowledge and can be applied in their daily lives. The method used in this activity is the method of lecturing, question and answer and direct practice, the participants who attend consist of mothers, while the material is given knowledge about waste, the dangers of waste and its impacts, as well as the practice of making handicrafts. Activities carried out at the homes of local residents in the form of a workshop meeting. The results obtained were that the use of plastic which was applied in the community service activities of the Shanti Bhuana Institute was a new activity for mothers who participated in these activities, the mothers were very enthusiastic in these activities as seen from their presence in this activity Direct practice allows them to know directly how to make economically valuable products. From this activity, it can be concluded that the community service activities carried out have a good impact because some women can practice how to manufacture products by utilizing plastic waste to become economically valuable products.
\end{abstract}

Keywords: economic value; plastic waste; women empowerment

\begin{abstract}
Abstrak: Sampah kresek merupakan salah satu limbah plastik yang banyak ditemui disekitar desa Suka Maju, kurangnya pengetahuan masyarakat dalam memanfaatkan dan mengolah sampah kresek menjadi produk yang bernilai ekonomis, untuk itu perlu dilakukan kegiatan pengabdian masyarakat yang dapat memberikan pengetahuan tentang pengolahan sampah kresek. tujuan kegiatan ini adalah memberikan pengetahuan kepada masyarakat tentang pengolahan sampah kresek yang banyak dijumpai oleh ibu-ibu yang ada di desa Suka Maju sehingga mereka mendapatkan pengetahuan baru dan dapat diterapkan dalam kehidupan mereka sehari-hari. Metode yang digunakan dalam kegiatan ini adalah metode ceramah, tanya jawab dan praktik secara langsung, peserta yang hadir terdiri dari ibu-ibu. Hasil yang diperoleh bahwa pemanfaatan plastik kresek yang diterapkan dalam kegiatan pengabdian masyarakat Institut Shanti Bhuana merupakan kegiatan yang baru bagi ibu-ibu yang mengikuti kegitan tersebut, ibu-ibu sangat antusias dalam kegiatan tersebut terlihat dari kehadiran mereka dalam kegiatan ini dan kegiatan praktik yang dilakukan secara langsung membuat mereka secara langsung dapat mengetahui bagaimana cara membuat produk yang bernilai ekonomis. Dari kegiatan ini dapat memberikan dampak yang baik karena sebagian ibu-ibu dapat mempraktikan cara pembuatan produk dengan memanfaatkan sampah plastik kresek menjadi produk bernilai ekonomis.
\end{abstract}

Kata kunci: bernilai ekonomis; pemberdayaan perempuan; sampah kresek 
Available online at https://jurnal.stmikroyal.ac.id/index.php/jurdimas

\section{PENDAHULUAN}

Kabupaten Bengkayang terletak di Provinsi Kalimnatan Barat, yang mempunyai 17 kecamatan dan salah satu Kecamatannya yaitu Sungai Betung yang terdiri dari empat desa yaitu desa Suka Maju, desa Suka bangun, desa Cipta Karya dan desa Karya Bhakti.

Sektor pendapatan masyarakat di Kecamatan Sungai Betung berasal dari Pertanian, peternakan, pertambangan dan Perkebunan salah satunya terdapat di Desa Suka Maju, namun lebih menonjol adalah sektor pertanian (BPS Bengkayang 2019) disektor pertanian mereka mengandalkan hasil padi yang di tanam di sawah dan ditanam 1 tahun sekali begitu pula dengan padi yang ditanam diladang yang mereka paen 1 tahun sekali, selanjutnya mereka manfaatkan lahan-lahan yang ada untuk menanan jagung, kemudian dari sektor pertambangan memanfaatkan lahan sebagai tempat untuk tambang emas. Dari sektor perkebunan mereka memanfaatkan kebun karet sebagai penghasilan tambahan.

Tidak ada sumber penghasilan lain yang bisa mereka andalkan untuk menunjang ekonomi keluarga, terutama bagi kaum perempuan yang berprofesi sebagai petani rendahnya pendidikan serta minimnya pengetahuan yang mereka miliki membuat mereka hanya mengandalkan alam dan bergantung pada alam. Permasalahan lain yang terdapat di desa Suka Maju adalah belum ada pengelolaan sampah sehingga banyaknya sampah di desa tersebut mendapat perhatian dari pemerintah desa Suka Maju, diperlukan penangan khusus untuk memberikan pandangan serta pengetahuan cara pengolahan sampah yang tepat dan dimanfaatkan menjadi pupuk yang dapat digunakan sendiri maupun diperjual belikan atau menjadi barang ekonomis yang dapat diolah dari limbah sampah bahkan dimanfaatkan menjadi bank sampah (Wardany, Sari, \& Mariana, 2020) manfaat lain adalah menjaga kelestarian lingkungan seperti yang dikemukakan oleh (Marliani, 2014) Sampah juga dimanfaaatkansebagai bahan baku pembuatan sebagai tas dan dompet.

Melihat permasalahan yang terjadi didesa tersebut timbul keinginan untuk melakukan kegiatan pengabdian yang diikuti oleh ibu-ibu yang ada di desa Suka Maju, kegiatan ini berupa pendampingan guna meningkatkan pengetahuan mereka melalui pemberdayaan masyarakat, seperti yang dikemukan (Suswanto, Handoko, \& Sabiq, 2013) pemberdayaan masyarakat berbasis kearifan lokal dapat diperoleh melalui model community development yang dapat diimplementasikan melalui pelatihan-pelatihan dan pendampingan untuk meningkatkan kemampuan sumber daya manusia. Selain itu dengan dilakukan kegiatan pendampingan masyarakat mereka dapat melihat potensi dan memanfaatkan potensi tersebut sehingga menjadi produk yang bernilai ekonomis (Vuspitasari and Ewid 2020)

Selain itu (Boakye-Acha, Mensah, Aidoo, \& Osei-Agyemang, 2012) menyatakan bahwa peran perempuan dalam bidang pengolahan pertanian masih sangat rendah sehingga perlu adanya dukungan dari pemerintah melalui kegiatan non pertanian yaitu melalui program pemberdayaan yaitu pelatihan untuk meningkatkan pedapatan rumah tangga, artinya bahwa pemerintah mempunyai peran dalam memberikan pengetahuan berupa pelatihan kepada masyarakat guna meningkatkan pengetahuan dan kreativitas mereka dalam mengembangkan potensi-potensi 
Available online at https://jurnal.stmikroyal.ac.id/index.php/jurdimas

yang ada (Kartika 2013).

Dalam hal ini kegiatan pemberdayaan masyarakat yang dilakukan berupa pendampingan pengolahan sampah kresek sebagai bahan baku pembuatan bunga sehingga bernilai ekonomis dan harapannya dapat memberi pengetahuan bagi ibu-ibu di desa Suka Maju dan menjadikan hasil olahan tersebut sebagai sumber penghasilan tambahan untuk menunjang ekonomi keluarganya.

\section{METODE}

Dalam menjalankan kegiatan pengabdian masyarakat metode yang dilakukan adalah FGD (focus group discussion) dengan menggunakan metode ini diharapkan masyarakat lebih terbuka dalam menyampaikan pendapat (Deffrinica and Vuspitasari 2019). Selain itu metode yang dgunakan adalah metode praktek secara langsung Adapun tahapannya sebagai berikut:

1. Tahap koordinasi dengan mitra dan menggali permasalahan Kegiatan awal dilakukan adalah berkoordinasi dengan perangkat desa Suka Maju, menggali perma-salahan yang terjadi di desa tersebut diantaranya masih banyak ibu-ibu yang ingin memiliki penghasilan tambahan namun belum memiliki modal yang cukup, rendahnya pengetahuan tentang pemanfaatan potensi-potensi alam yang belum dimaksimalkan dengan baik oleh masyarakat setempat, hal lain yang ditemukan adalah rendahnya kesadaran masyarakat akan pentingnya kebersihan lingkungan, belum ada masyarakat yang tertarik untuk mengolah sampah karena masih banyak ditemukan sampah-sampah kresek di sekitar Desa Suka Maju.

2. Tahap persiapan, Setelah mengetahui permasalahan yang dihadapai maka tim menyepakati untuk memberikan pengetahuan baru tentang keinginan ibu-ibu yang ingin memiliki penghasilan tambahan namun dengan modal yang sangat terbatas dengan memanfaatkan sampah kresek, tahap selanjutnya yang dilakukan adalah mempersiakan materi-materi tentang pengetahuan sampah, bahaya sampah serta manfaat sampah, dan selanjutnya adalah melakukan kegiatan praktek dengan memanfaatkan sampah kresek menjadi suatu produk bernilai ekonomis yaitu hasil kerajinan tangan berupa tanaman hias yang dibuat sedemikian rupa sehingga memiliki nilai ekonomis.

3. Tahap pelaksanaan dan solusi yang diberikan, Tahap pelaksanaan terbagi menjadi dua tahap yaitu tahap sosialisasi dan tahap praktik ditahap sosialisai masyarakat diberi pengetahuan tentang sampah, bahaya sampah serta dampak-dampak yang ditimbulkan oleh sampah dan manfaat dari sampah itu sendiri, setelah mengetahui informasi tersebut hal selanjutnya dilakukan adalah mempraktekkan secara langsung bagaimana cara mengolah sampah kresek, Tahap ini dimana ibu-ibu diminta untuk membawa sampah-sampah kresek yang ada disekitar rumahnya atau plastik kresek yang sering kali ibu-ibu temukan Ketika berbelanja di pasar, kemudian menyediakan setrika, gunting, kawat, lem tembak, lilin dan korek api, kegiatan praktek ini dimulai dengan mengunting plastic kresek tersebut menjadi potonganpotongan yang diinginkan dengan 
Available online at https://jurnal.stmikroyal.ac.id/index.php/jurdimas

menyesuiakan warna tanaman hias yang ingin dibuat, kemudian membentuk plastik kresek tersebut sedemikian rupa sehingga menjadi bentuk-bentuk yang diinginkan.

\section{PEMBAHASAN}

Kegiatan pengabdian masyarakat dilakukan selama dua kali pertemuan yang dijalankan oleh dosen Institut Shanti Bhuana dan melibatkan dua orang mahasiswa, kegiatan dilakukan pada tanggal 19 Agustus 2020 dan 24 Agustus 2020, peserta kegiatan di batasi karena mengingat kondisi yang tidak memungkinkan karena pandemic virus corona, di pertemuan pertama yaitu pada tanggal 19 Agustus 2020 pukul 08.00 - 12.00 WIB, kegiatan yang dilakukan adalah memberi pengetahuan tentang sampah, bahaya sampah serta dampak-dampak yang ditimbulkan oleh sampah dan manfaat dari sampah itu sendiri, peserta yang hadir terdiri dari ibu-ibu, kegiatan dilakukan dirumah warga setempat dengan memanfaatkan ruang tamu, kegiatan juga dilakukan secara sarasehan dengan mendampingi secara langsung kegiatan tersebut, tujuannya memberikan pengetahuan kepada ibu-ibu bahwa sampah juga memiliki manfaat ekonomis selain itu memberi pengetahuan bagiamana menjadikan lingkungan yang sehat agar dapat mereka tularkan kepada anak-anaknya, seperti diketahui bahwa dalam menjaga lingkungan yang sehat perlu dipupuk sejak usia dini. Sehingga nilai-nilai kepedulian terhadap lingkungan dapat mereka terapkan dalam kehidupannya kelak (Widijatmoko, Iswahyudi, and Nera 2018). Setelah menjelaskan tentang sampah, selanjutnya mempraktekan secara bertahap bagaimana proses pembuatan kerajinan tangan memanfaatkan kantong kresek tersebut. Tahap pertama adalah peserta yang terdiri dari ibu-ibu tersebut melakukan pemilahan warna kantong tersebut setelah itu digunting berbentuk kotak dan disetrika, tujuannya adalah untuk dapat membuat plastic tersebut keras dan mudah dibentuk, ditahap ini para peserta diminta mempraktekan hal yang sama guna mengetahui bagaimana proses pengerasan yang terjadi pada plastic kresek tersebut. Ibu-ibu sangat antusias melaukan praktek tersebut hal ini dapat dilihat pada gambar 1 .

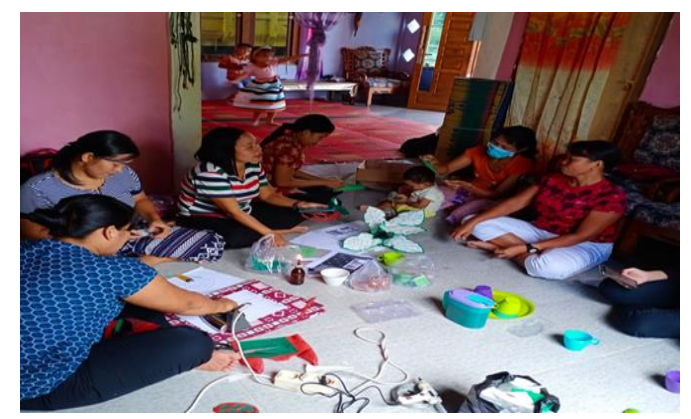

Gambar 1: Proses pemilihan warna plastik kresek.

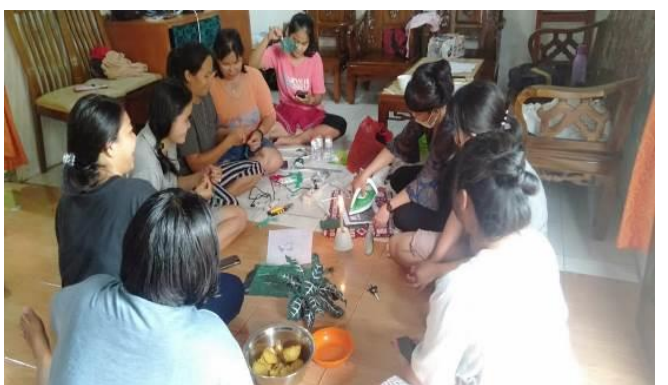

Gambar 2: Proses setrika plastik kresek oleh narasumber.

Pada Gambar 1 dan 2 Tim Memberikan Materi dalam Pembuatan kerajinan tangan dari bahan plastic kresek, Setelah melakukan kegiatan tersebut peserta mendapatkan pengetahuan baru tentang bagaimana mengolah kantong kresek yang sering kali banyak ditemui dihampir setiap rumah, dan biasanya menjadi sampah, dengan pengetahuan tersebut harapanya mereka dapat terap- 
Available online at https://jurnal.stmikroyal.ac.id/index.php/jurdimas

kan dilingkungan keluarga, karena Pendidikan se-sungguhnya berada di lingkungan keluarga, anak-anak mendapatkan pelajaran Ketika mereka berada di rumah dan meniru apa yang dilakukan oleh orang tua (Vuspitasari 2020). Begitu pula jika Sampah yang selama ini menjadi permasalahan bagi lingkungan jika diolah dengan baik, dimanfaat kan dengan baik dapat memberikan peluang secara ekonomis bagi ibu rumah tangga dan remaja. Pengolahan sampah yang belum maksimal hendaknya menjadi peluang yang menjanjikan bagi mereka yang kreatif dan tentunya diperlukan ketekunan untuk menjalankannya, terutama bagi ibu rumah tangga yang tidak memiliki pekerjaan, dengan menjalankan kegiatan ini harapannya ibu rumah tangga maupun remaja mendapatkan inspirasi sehingga mereka dapat memanfaatkan ini sebagai suatu peluang yang baik dilingkungan mereka terutama ekonomi keluarga (Wardany, Kusuma, Sari, \& Mariana, 2020)

\section{SIMPULAN}

Melalui kegiatan pengolahan sampah kresek harapannya para peserta semakin mengetahui bahwa sampah kresek mempunyai peluang dalam meningkatkan ekonomi masyarakat jika dimanfaatkan dengan baik. Perlu adanya kegiatan serupa guna memberikan pengetahuan terutama bagi ibu rumah tangga yang tidak memiliki pekerjaan dengan adanya kegiatan pemanfaatan sampah mereka dapat memperoleh ilmu baru dan mempraktekan pengetahuan tersebut sehingga mereka mendapatkan penghasilan tambahan dan membantu ekonomi keluarga.

\section{UCAPAN TERIMA KASIH}

Ucapan terima kasih kepada Pusat Riset dan pengabdian masyarakat Institut Shanti Bhuana yang telah membantu. kepada Kepala Desa yang telah memberikan kesempatan untuk melakukan pengabdian masyarakat di Desa Suka Maju, ucapan terima kasih untuk peserta yang mengikuti kegiatan ini dengan antusia dan penuh semangat.

\section{DAFTAR PUSTAKA}

Suswanto, B., Handoko, W., \& Sabiq, A. (2013). Model community development sebagai strategi pemberdayaan berbasis kearifan lokal. Jurnal Review Politik, 3(2), 298-312.

BPS Bengkayang. 2019. Statistik Kesejahteraan Rakyat Kabupaten Bengkayang 2019.

Deffrinica, and Benedikta Kikky Vuspitasari. 2019.

"Pendampingan Terhadap

Kelompok Ibu Hamil Dalam Pembuatan BPJS Kesehatan Di Daerah 3 T." CARADDE: Jurnal Pengabdian Kepada Masyarakat 2(1):85-90. doi: 10.31960/caradde.v2i1.236.

Kartika, Ray. 2013. "Peluang Mengembangkan Kewirausahaan Desa Berbasis Potensi Desa (Studi Deskriptif Di Desa Karang Rejo Kecamatan Negeri Katon Kabupaten Pesawaran, Kampung Suka Jawa Kecamatan Bumi Ratu Kabupaten Lampung Tengah Dan Desa Sidoasri Kecamatan Candi Puro Kabupate." Jurnal Bina Praja 05(04):281-300. doi: 10.21787/jbp.05.2013.281-300.

Marliani, $\quad$ Novi. 2014. 
Available online at https://jurnal.stmikroyal.ac.id/index.php/jurdimas

$\begin{array}{lr}\text { "PEMANFAATAN } & \text { LIMBAH } \\ \text { RUMAH TANGGA ( SAMPAH } \\ \text { ANORGANIK ) SEBAGAI } \\ \text { BENTUK IMPLEMENTASI." } \\ \text { Jurnal Ilmiah Pendidikan MIPA } \\ \text { 4(2):124-32. }\end{array}$

S. Boakye-Achampong, J. Osei Mensah, R. Aidoo, K. Osei-Agyemang. 2012. "The Role of Rural Women in the Attainment of Household Food Security in Ghana: A Case Study of Women- Farmers in Ejura-Sekyeredumasi District." International Journal of Pure and Applied Sciences and Technology 12(1):29-38.

Vuspitasari, Benedhikta Kikky. 2020. "Literasi Keuangan Sekolah." 1(2):98-105.
Vuspitasari, Benedhikta Kikky, and Angelus Ewid Ewid. 2020. "Peran Kearifan Lokal Kuma Dalam Mendukung Ekonomi Keluarga Perempuan Dayak Banyadu." Sosiohumaniora 22(1). doi: 10.24198/sosiohumaniora.v22i1.2 4078 .

Wardany, Kusuma, Reni Permata Sari, and Erni Mariana. 2020. "Sosialisasi Pendirian 'Bank Sampah' Bagi Peningkatan.” 4(2):364-72.

Widijatmoko, Engelbertus Kukuh, Didik Iswahyudi, and Sirilus Sakti Nera. 2018. "Sampah Plastik Melalui Program Green School Festival." Jurnal Pendidikan Vol 8. 